\title{
TUBODALAM PERSPEKTIF EKOLOGI BUDAYA PETANI KERAMBa JaRING APUNG DI KaWAsaN DANAU maniNJau prouinsi sumatera barat
}

\section{TUBO IN THE CULTURAL ECOLOGY PERSPECTIVE OF THE FLOATING NET CAGE FARMER IN THE LAKE MANINJAU IN WEST SUMATERA}

\author{
Silvia Devi ${ }^{1}$, Rois Leonard Arios ${ }^{2}$ \\ 1,2, Balai Pelestarian Nilai Budaya Sumatera Barat \\ Jl. Raya Belimbing No.16A Kuranji, Padang \\ e-mail: silvia160681@gmail.com, rolear72@yahoo.co.id
}

DOI: 10.30959/patanjala.v13i1.646

\begin{abstract}
Abstrak
Tulisan ini bertujuan menggambarkan bagaimana strategi petani Keramba Jaring Apung (selanjutnya disebut KJA) di Kawasan Danau Maninjau Provinsi Sumatera Barat dalam menghadapi tubo yaitu peristiwa kematian ikan secara massal di Danau Maninjau akibat keracunan. Pendekatan ekologi budaya digunakan untuk menganalisis dan menjawab permasalahan penelitian. Penelitian menggunakan metode kualitatitf dengan pengumpulan data melalui studi pustaka, wawancara, dan observasi. Hasil penelitian menggambarkan bahwa petani KJA menghadapi peristiwa tubo sebagai proses alam yang harus diterima sehingga mereka harus beradaptasi agar kehidupan ekonomi mereka dapat bertahan. Adaptasi petani KJA didasarkan pada pemahaman mereka terhadap lingkungan, tubo, teknologi yang ada, dan nilainilai religi yang mereka miliki. Dengan pendekatan ekologi budaya petani KJA mampu menghadapi perubahan alam dan teknologi sehingga mereka dapat tetap bertahan.
\end{abstract}

Kata Kunci: tubo, ekologi budaya, petani KJA, umbalan

\begin{abstract}
This work was intended to draw the strategy of the floating net cage farmers (Keramba Jaring Apung, KJA) in the Lake Maninjau in West Sumatera to deal with the 'tubo', a mass death of fish as a result of poison-laced bait. To analyze and answer the research question, therefore the research employed the cultural ecology approach. The research also used the qualitative method with the data collection by literature study, interviews, and observations. The study revealed that the farmers accepted the 'tubo' inevitably as a natural fact. As the consequence of it, they couldn't help but adapted in order to survive economically. The adaptation process is based on their understanding of the environment, the 'tubo', the existing technology, and their religious values. They were able to adapt to natural and technological changes because of the ecological and cultural approaches they applied. As a result, they were able to survive.
\end{abstract}

Keyword: tubo, cultural ecology, KJA farmers, umbalan

\section{A. PENDAHULUAN}

Danau Maninjau di Provinsi Sumatera Barat merupakan salah satu danau yang terbentuk akibat letusan gunung merapi. Berdasarkan data LIPI-ITB tahun 2015 yang dikutip oleh Marzuki \& Ali (2018) menjelaskan bahwa Danau Maninjau memiliki luas permukaan air 9.737,50 ha, panjang maximum $16.46 \mathrm{~km}$, lebar maximum $7,8 \mathrm{~km}$, kedalaman maximum 
$168,0 \mathrm{~m}$, kedalaman rata- rata $105,02 \mathrm{~m}$, panjang garis pantai $52,68 \mathrm{~km}$, shoreline development $1,51 \mathrm{~km}$, tingkat kedalaman relative (zr) 1,508\% (kurang stabil), volume air 10.226.001.629,20 $\mathrm{m}^{3}$, tipe danau vulkono tectonic, elevasi 461463 mdpl, daerah tangkapan air 13.260 ha. Mengutip pendapat Verbek, Pribadi, Mulyadi, dan Pratomo (2007) menjelaskan Danau Maninjau sebagai danau vulkanik memiliki dinding kaldera dengan ketinggian 1200-1400 mdpl.

Sebagian kawasan Danau Maninjau dimanfaatkan sebagai lahan perikanan oleh petani Keramba Jaring Apung (selanjutnya disebut KJA) yang secara administratif masuk dalam wilayah Kecamatan Tanjung Raya Kabupaten Agam yang meliputi 8 nagari (pemeritahan setingkat desa) yaitu Nagari Tanjung Alai, Nagari Maninjau, Nagari Bayur, Nagari II Koto, Nagari Koto Kaciak, Nagari Sungai Batang, Nagari Koto Malintang, dan Koto Gadang VI Koto

KJA adalah sarana pemeliharaan ikan di danau dengan menggunakan wadah keramba empat persegi yang dibentuk dari beberapa bahan yaitu pelampung yang biasanya menggunakan drum plastik, , jaring, besi, dan kayu. Sedangkan di atas KJA umumnya terdapat rumah jaga, tempat pakan, dan kolam karantina (Ardi, 2013)

Penggunaan KJA memberikan keuntungan yang sangat besar sehingga masyarakat menjadikan KJA sebagai sumber perekonomian utama. Tahun 2005 sebagai awal penggunaan KJA, jumlahnya sudah mencapai 10.125 unit. Pada tahun 2009 terjadi penurunan jumlah KJA menjadi 8.829 unit, namun tahun 2012 meningkat kembali menjadi 15.863 unit dan tahun 2013 sebanyak 15.060 unit (Syandri, 2016; Syandri et al., 2015)

Banyaknya KJA di Kawasan Danau Maninjau disebabkan keuntungan yang sangat signifikan dan relatif lebih mudah diperoleh oleh petani KJA sehingga tidak memperhitungkan daya dukung danau (Noferi, 2003; Syandri et al. 2015; Endah and Nadjib 2017; Praditya, Sabar, \& Yulia 2014; Marzuki \& Ali, 2018). Eksploitasi danau tersebut menyebabkan keseimbangan ekosistem terganggu yang memicu terjadinya tubo terutama pada setiap musim hujan tiba.

Tubo merupakan istilah masyarakat lokal untuk menyebut umbalan atau upwelling yaitu kondisi naiknya massa air dari lapisan dasar ke permukaan akibat adanya perbedaan suhu. Hal ini terjadi pada saat awal musim penghujan dengan intesitas tinggi sehingga suhu permukaan rendah sehingga bagian bawah yang lebih hangat naik ke permukaan. Hal ini mengakibatkan materi organik yang didominasi pakan ikan dan sisa metabolisme naik dan mengganggu asupan oksigen yang mengakibatkan ikan keracunan amonia dan sulfur dan berujung pada kematian.

Kenyataan ini menggambarkan bahwa petani KJA tidak hanya dihadapkan keuntungan yang banyak. Tetapi juga dihadapkan dengan segala kemungkinan kerugian dari adanya peristiwa umbalan atau upwelling (tubo) yang terjadi di setiap tahunnya. Kematian ikan secara massal yang seringkali terjadi memberikan kerugian yang sangat besar pada petani KJA.

Kebijakan Pemerintah Kabupaten Agam mengatasi persoalan tublo adalah melalui Gerakan Save Maninjau. Salah satu bentuk penyelamatan Danau Maninjau yaitu dengan mengurangi jumlah keramba yang hingga tahun 2018 mencapai lebih dari 18.000 unit. Gerakan ini tidak mudah dilaksanakan karena adanya berbagai kepentingan masyarakat terutama Petani KJA dalam pemenuhan kebutuhan hidupnya. Bahkan Pemerintah Propinsi Sumatera Barat juga telah mengeluarkan kebijakan terkait pengelolaan kelestarian Danau Maninjau. Namun juga belum mampu memperbaiki ekosistem Danau Maninjau terbukti masih tingginya angka kematian ikan akibat upwelling. Hal ini menjadi penting untuk melihat bagaimana usaha para petani KJA dalam menjaga 
kelestarian Danau Maninjau yang keadaannya sekarang sudah melebihi daya tampung danau.

Tingkat ketergantungan mata pencaharian masyarakat di Kawasan Danau Maninjau terhadap KJA cukup tinggi. Namun keadaan yang memaksa, maka jumlah keramba mereka saat ini sudah semakin berkurang. Hal ini disebabkan banyaknya kerugian yang menimpa mereka selama kurun waktu beberapa tahun belakangan ini. Agar mereka tetap bisa bertahan dalam mata pencaharian berkeramba, mereka harus melakukan strategi adaptasi terkait peristiwa tubo yang terus menghantui mereka.

Danau Maninjau merupakan salah satu sumber daya alam yang tidak bisa semata-mata diambil keuntungannya tanpa memelihara kelestariannya. Manusia dan alam lingkungannya saling memengaruhi dan tidak bisa dipisahkan. Keterkaitan manusia dan lingkungannya seperti yang ditekankan oleh Marfai (2013) bahwa sejak dahulu manusia seperti halnya makhluk hidup berinteraksi dan mempunyai ketergantungan dengan lingkungan hidupnya.

Manusia di manapun berada memiliki kebudayaan yang tergantung pada keadaan alam sekitar. Oleh karena itu, jika terjadi perubahan yang akan mengancam keberadaan mereka maka akan dilakukan berbagai rangkaian antisipasi agar keberadaan mereka tetap bertahan. Antisipasi ini sebagai wujud adaptasi terhadap perubahan. Hal ini sesuai dengan yang diungkapkan oleh Purwanto (2000) bahwa manusia akan selalu berusaha menyesuaikan diri dengan berbagai perubahan yang terjadi di lingkungannya dengan melahirkan pola-pola tingkah laku yang baru. Oleh karena itu pola adaptasi yang dilakukan memiliki perbedaan antara satu kelompok masyarakat dengan masyarakat lainnya.

Pola tingkah laku tersebut lahir dari perilaku yang tercipta dari serangkaian aturan dari pengalaman dan pemahaman perilaku alam dengan kesadaran penuh. Hal ini seperti yang diungkapkan oleh Marfai (2013) bahwa manusia dengan alam harus menjalankan etika lingkungan. Hal ini bertujuan agar alam terhindar dari eksploitasi yang berlebihan.

Beberapa pendapat di atas sejalan dengan konsep ekologi budaya. Steward, J. H (1955) menyebut ekologi sebagai adaptation to environment. Sejalan dengan Steward, Sutton and Anderson (2014) menyebut dengan konsep ekologi manusia, yaitu hubungan antara kebudayaan dengan lingkungan alam, termasuk bagaimana kebudayaan mampu menyelesaikan masalah, bagaimana manusia memahami lingkungannya, dan berbagi pengetahuan tentang lingkungan alamnya. Analisis ekologi budaya dapat dipahami dalam 3 hal yaitu: hubungan teknologi eksploitasi sumber daya alam dengan lingkungan; tindakan masyarakat dalam ekspoitasi; dan sistem nilai dan religi yang berlaku di masyarakat (Steward, 1955).

Analisis ekologi budaya masih relevan dipakai saat ini, seperti Kristiawan (2017) yang menganalisis pola adaptasi tiga komunitas di Jambi yaitu orang Talang Mamak, orang Jawa sebagai pendatang, dan orang Melayu. Tiga komunitas ini memiliki strategi adaptasi yang berbeda untuk memenuhi stabilitas kebutuhan ekonomi masing-masing.

Kajian lainnya seperti yang dilakukan oleh Fransiska (2019) menggambarkan bagaimana adaptasi yang dilakukan oleh transmigran Jawa di Desa Rasau Jaya Satu melalui pendekatan ekologi budaya. Transmigran berhasil mengolah lahan gambut untuk pertanian mereka, mampu beradaptasi terhadap lingkungan alam, mengadopsi sistem pertanian lokal orang Dayak, dan beradaptasi terhadap kehidupan sosial yang mayoritas orang Dayak.

Penelitian Helmi, Alfian, and Arif (2012) mengkaji strategi adaptasi masyarakat Desa Pulau Panjang. Adaptasi yang dilakukan dengan variasi sumber pendapatan, memanfaatkan hubungan 
sosial, memobilisasi anggota rumah tangga, melakukan penganekaragaman alat tangkap dan melakukan perubahan daerah penangkapan serta melakukan strategi lainnya.

Penelitian Puhili (2013) tentang adaptasi budaya suku Komoro yang mengalami dampak negatif secara langsung dari keberadaan industri PT Freeport. Tempat tinggal masyarakat suku Komoro di setiap pinggir sungai yang telah menjadi daerah pembuangan limbah pasir mineral PT Freeport sehingga keberadaan kampung dan budayanya terancam punah.

Penelitian terkait dengan Danau Maninjau dilakukan oleh Noferi (2003) yang mengungkapkan bahwa pengelolaan Danau Maninjau saat ini belum memperhatikan aspek keberlanjutan dari sumber daya alam. Pencemaran menyebabkan kerugian yang sangat besar bagi masyarakat dan penurunan aktivitas perekonomian serta memperberat kehidupan masyarakat. Hal tersebut bisa dijawab dari hasil penelitian Syandri et al. (2015) bahwa peningkatan produksi ikan dan tingkat penghasilan akan mempengaruhi status sosial petani KJA. Sehingga ada kecenderungan untuk eksploitasi danau melalui KJA.

Hasil penelitian (Endah \& Nadjib (2017) menyimpulkan adanya tumpang tindih penguasaan dan pengelolaan Danau Maninjau mengakibatkan terjadinya degradasi ekologi. Nilai budaya lokal sangat memengaruhi perilaku masyarakat dalam penguasaan danau sebagai lahan KJA sehingga diperlukan model pelestarian danau.

Penelitian Praditya, Sabar, and Yulia (2014), di Tanjung Sani Kecamatan Tanjung Raya. Digambarkan bahwa sebelum tahun 1990-an masyarakat Maninjau belum mengenal keramba, dan umumnya mereka memiliki mata pencaharian sebagai nelayan tangkap, petani, tukang kebun, dan peladang. Namun demikian, sejak tahun 1991 sampai 2000 mereka beralih pekerjaan menjadi petani KJA. Pekerjaan ini sangat menguntungkan bagi mereka karena pekerjaan tidak sulit namun mendatangkan keuntungan yang banyak. Namun satu hal yang harus mereka hadapi setiap tahun sejak tahun 1997 adalah adanya tubo belerang yang menimbulkan kerugian besar karena ikan mati secara massal. Kondisi tersebut tidak menyurutkan niat mereka untuk tetap berkeramba.

Berdasarkan literatur di atas, dikatakan bahwa usaha manusia untuk beradaptasi bukanlah pekerjaan yang mudah. Dengan demikian penelitian ini sangat penting agar dapat menjadi rujukan bagaimana petani KJA tetap bertahan dengan meminalisir kerusakan lingkungan alam.

Berdasarkan uraian latar belakang di atas tulisan ini bertujuan menganalisis strategi petani KJA dalam menghadapi tubo di kawasan Danau Maninjau dalam perspektif ekologi budaya.

\section{B. METODE PENELITIAN}

Penelitian dilakukan di kawasan Danau Maninjau dengan fokus pengumpulan data di Kecamatan Tanjung Raya pada bulan Maret tahun 2018. Metode penelitian yang digunakan dalam kajian ini adalah metode kualitatif deskriptif. Pengumpulan data dilakukan dengan cara studi pustaka, pengamatan, dan wawancara mendalam Afrizal (2014). Studi pustaka dilakukan melalui buku, majalah, buletin, dan koran yang berisi konsep-konsep dan teori-teori yang terkait dengan tujuan penelitan.

Pengamatan dilakukan dengan mengamati secara langsung kegiatan petani keramba seperti memberi pakan ikan, kegiatan membersihkan danau dari bangkai ikan, kegiatan pada saat panen, dan kegiatan memasarkan hasil panen yang berlangsung di Kawasan Maninjau. Adapun para petani keramba yang diobservasi adalah para petani keramba jaring apung, baik sebagai pemilik, maupun sebagai anak buah (anak buah panen atau anak buah pemberi pakan).

Wawancara mendalam dilakukan untuk menggali lebih dalam tentang 
strategi adaptasi petani keramba jaring apung pada peristiwa tubo di Maninjau. Para petani keramba jaring apung yang diwawancarai adalah para petani keramba yang telah menggeluti dunia keramba minimal 5 tahun lamanya dan masih memiliki keramba yang bertahan sampai saat ini. Selain itu, para anak buah, baik anak buah pemberi pakan, dan anak buah panen juga diwawancarai terkait pengetahuan mereka akan peristiwa tubo. Sebagai data pembanding, peneliti juga telah mewawancarai para mantan petani keramba yang saat ini bisa dikatakan tidak lagi bekerja sebagai petani meskipun masih memiliki sejumlah keramba. Informan diwawancarai sebanyak 10 orang yang diperoleh secara snowball dan jumlahnya tidak ditentukan secara ketat namun sesuai dengan kebutuhan data (purposive sampling).

\section{HASIL DAN BAHASAN \\ 1. Petani KJA di Kawasan Danau Maninjau}

Kawasan Danau Maninjau secara administratif berada di Kecamatan Tanjung Raya Kabupaten Agam Provinsi Sumatera Barat memiliki 9 nagari (setingkat desa) dengan luas wilayah $244.03 \mathrm{~km}^{2}$ atau $10.33 \%$ dari luas Kabupaten Agam. Sebagian besar penduduk sebagai petani KJA yang diperkenalkan melalui program Sarjana Pembangunan Pedesaan pada tahun 1990. Salah satu programnya adalah memperkenalkan budidaya ikan air tawar dengan jaring apung sebagai wadah pemeliharaan ikan. Teknologi ini semakin berkembang hingga menjadi mata pencaharian yang dominan bagi masyarakat di Kawasan Danau Maninjau. Tabel berikut bisa menjelaskan perkembangan jumlah KJA hingga tahun 2016.

Tabel 1. Perkembangan Jumlah KJA dari Tahun 2014 sampai 2016

\begin{tabular}{llccc}
\hline \multirow{2}{*}{ No } & \multirow{2}{*}{ Nagari } & \multicolumn{3}{c}{ Jumlah KJA } \\
\cline { 3 - 5 } & & 2014 & 2015 & 2016 \\
\hline $\mathbf{1}$ & Maninjau & 1843 & 1597 & 1934 \\
\hline
\end{tabular}

\begin{tabular}{llrrr}
\hline $\mathbf{2}$ & Bayua & 2856 & 4178 & 3691 \\
\hline $\mathbf{3}$ & II Koto & 866 & 866 & 726 \\
\hline $\mathbf{4}$ & Koto Kaciek & 1260 & 1409 & 827 \\
\hline $\mathbf{5}$ & $\begin{array}{l}\text { Koto Gadang VI } \\
\text { Koto }\end{array}$ & 200 & 200 & 514 \\
\hline $\mathbf{6}$ & Koto Malintang & 3650 & 3612 & 3834 \\
\hline $\mathbf{7}$ & Tanjung Sani & 4108 & 5461 & 3743 \\
\hline $\mathbf{8}$ & Sungai Batang & 1797 & 3285 & 1957 \\
\hline & Total & 16580 & 20608 & 17226 \\
\hline
\end{tabular}

Sumber : (Syandri, 2016)

Usaha keramba dimulai dari pembenihan, pembesaran bibit, dan pembesaran ikan sampai panen. Pembenihan dilakukan di areal persawahan agar lebih mudah mengontrol dan mengurangi resiko jika dilakukan di danau. Setelah cukup usia dan ukuran tertentu, dipindahkan ke KJA yang terdapat di danau. Jenis ikan yang umumnya dipelihara adalah ikan nila (Oreochromis niloticus) dan ikan mas (Cyprinus carpio, masyarakat setempat menyebut ikan rayo). Pemberian makanan dilakukan 3 kali sehari yaitu pagi, siang, dan sore.

Selain budidaya perikanan di danau, masyarakat juga mengusahakan budidaya perikanan darat, untuk memproduksi benih atau bibit ikan. Budidaya perikanan darat inilah secara signifikan mengurangi jumlah petani sawah yang ada karena petak-petak sawah yang dulu ditanami padi sekarang beralih menjadi tempat pengembangbiakan ikan.

Petani KJA ada juga yang melakukan usaha pembibitan nila di persawahan mulai ukuran sekitar $1 \mathrm{~cm}$ dijual ke petani KJA dengan harga untuk 10.000 ekor bibit seharga Rp.1.200.000,-. Sementara itu, bibit yang berumur satu bulan dijual dengan harga Rp.3.000.000,-Pemasaran bibit dilakukan di kawasan Danau Maninjau, Jambi, dan Medan. Keuntungan yang diperoleh petani KJA dari usaha pembibitan cukup besar dengan perhitungan untuk 10.000 ekor bibit, biaya pakan sebesar Rp.2.000.000,- (dengan harga pakan per karung sekitar Rp360.000,-). Dengan perhitungan tersebut akan diperoleh sekitar Rp. 1.000.000,-per bulan (Wawancara dengan Imam, pada 
tanggal 27 Maret 2018 di Nagari Tanjung Sanai).

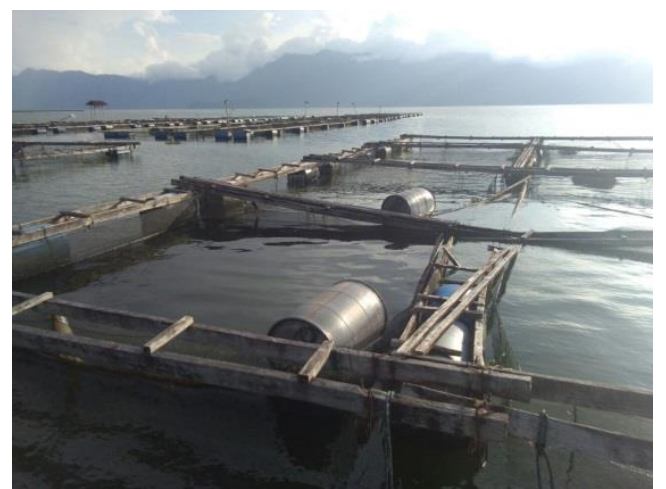

Gambar 1. KJA di Danau Maninjau Sumber: Dokumentasi Silvia Devi

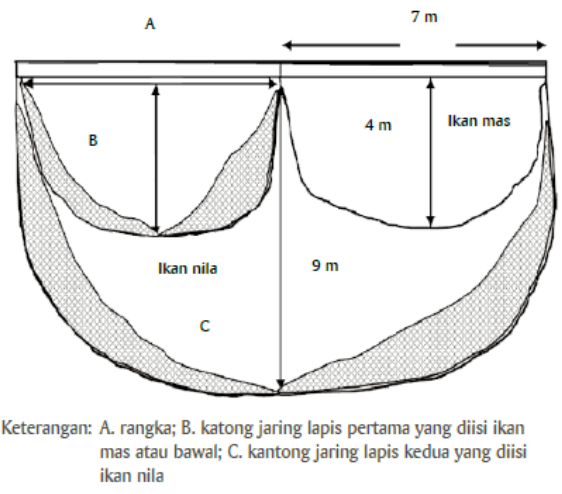

Gambar 2. Ilustrasi Bentuk KJA Sumber: Ardi, 2013

Usaha KJA merupakan jenis usaha dengan faktor resiko kerugian dan keuntungan yang cukup besar. Jika terjadi tubo maka resiko kerugian yang cukup besar terjadi. Namun demikian, sebagian petani KJA tetap mempertahankan usaha KJA karena mempertimbangkan besarnya keuntungan yang diperoleh jika tidak terjadi tubo. Salah seorang informan bernama Imam adalah orang yang pertama membuka usaha KJA. Baginya sulit rasanya meninggalkan dunia keramba ini meski jatuh bangun telah ia alami. Selama berkeramba ini pernah merasakan keuntungan yang besar dalam berkeramba. Namun kerugian besarpun pernah dialaminya, dan petani KJA lainnya di kawasan Danau Maninjau. Pada tahun
2009 Imam sempat memiliki 60 petak keramba yang berisi ikan mas Majalaya. Keramba tersebut mengalami kerugian disebabkan kematian ikan secara masal yang menyebabkan kerugian saat itu sekitar Rp600 juta (Wawancara dengan Imam, pada tanggal 27 Maret 2018 di Nagari Tanjung Sanai).

Tabel 2. Kematian Ikan secara Massal Akibat Umbalan

\begin{tabular}{lrrr}
\hline Tahun & $\begin{array}{l}\text { Total } \\
\text { KJA } \\
\text { (unit) }\end{array}$ & $\begin{array}{l}\text { Total } \\
\text { Mati } \\
\text { (ton) }\end{array}$ & \multicolumn{1}{l}{$\begin{array}{l}\text { Kerugian } \\
\text { (Rp Miliyar) }\end{array}$} \\
\hline 1997 & 2854 & 950 & 2,7 \\
\hline 2009 & 9830 & 13413 & 150 \\
\hline 2010 & 13129 & 1150 & 18,4 \\
\hline 2011 & 15860 & 250 & 4,375 \\
\hline 2013 & 16120 & 450 & 8,1 \\
\hline 2014 & 16520 & 680 & 13,6 \\
\hline 2015 & 16620 & 150 & 3,0 \\
\hline 2016 & 20620 & 600 & 12,0 \\
\hline Total & & 17643 & 212,175 \\
\hline Surber
\end{tabular}

Sumber : (Syandri, 2016)

Kerugian akibat tubo bagi sebagian petani KJA yang bermodal kecil akan sangat memberatkan untuk kembali memulai usaha. Namun, hal ini tidak bisa diatasi dengan banyaknya toke (orang yang meminjamkan uang kepada petani KJA dan hasilnya dijual ke toke tersebut) yang akan memberi modal. Di satu sisi hal ini sangat membantu untuk memulai kembali usaha KJA, namun di sisi lain berdampak pada ketergantungan petani KJA terhadap si toke. Pemberian modal bisa pula dalam bentuk penyediaan bibit atau perlengkapan KJA dengan pembagian hasil penjualan ikan yang tetap akan menguntungkan si pemilik modal. Jika dalam bentuk pinjaman uang, maka si petani KJA diwajibkan membayar uang pinjamannya berikut bunga sesuai kesepakatan kedua belah pihak setelah panen ikan tiba. Jika gagal panen (tubo), toke tetap akan memberikan pinjaman uang sehingga si petani KJA akan semakin terlilit hutang.

Temuan yang serupa dikemukakan oleh Abdoellah (2017) bahwa yang 
dilakukan oleh para penduduk yang terkena dampak pembangunan PLTA Cirata Jawa Barat tergantung pada modal yang dimilikinya. Usaha bertahan hidup demi kelangsungan hidup dengan berbagai upaya peluang kerja yang ada dilakukan. Bagi penduduk yang memiliki modal maka akan tetap untuk usaha jaring terapung ataupun dagang, sementara bagi yang tidak miliki modal maka akan berusaha tenaganya dimanfaatkan sebagai buruh apapun bentuk pekerjaannya.

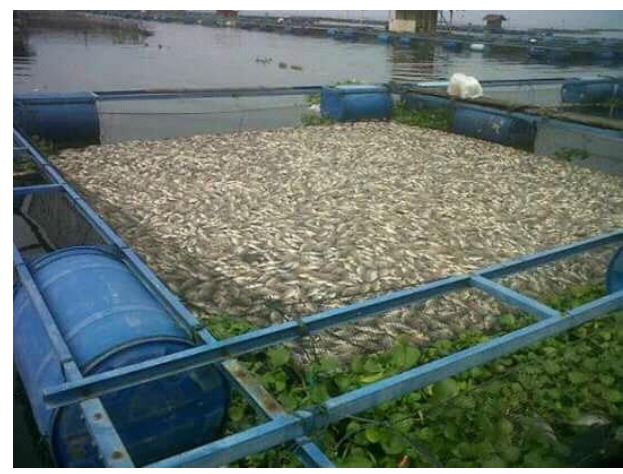

Gambar 3. Ikan Mati Akibat Tubo Sumber: Dokumentasi Silvia Devi

Oleh karena untuk bertahan sebagai petani KJA tidak bisa hanya mengandalkan satu mata pencaharian sebagai petani KJA, mereka biasanya memiliki lebih dari satu mata pencaharian. Aktivitas berkeramba tidak menghabiskan waktu yang banyak, petani dapat mengisi dengan aktivitas lain menangkap ikan dengan memancing atau mamukek. Aktivitas ini selalu mereka lakukan dengan menggunakan biduak. Hasil yang didapat bisa mencukupi kebutuhan sehari-hari mereka. Aktivitas menangkap ikan dengan menggunakan biduak masih terus dilakukan sampai saat ini. Seperti yang dilakukan oleh Yanrizal yang selalu memanfaatkan waktunya untuk menangkap ikan di danau. Bahkan ia sering mendapatkan ikan dalam jumlah besar (Wawancara dengan Yanrizal tanggal 26 Maret 2018 di Tanjung Sani).

\section{Pengetahuan Petani KJA Terhadap Tubo}

Tubo adalah istilah dalam Bahasa Minangkabau untuk menyebut tuba (racun ikan) dalam Bahasa Indonesia. Sebelum adanya KJA di Danau Maninjau petani keramba telah mengenal tubo yang dikonsepsikan sebagai sebuah peristiwa alam.

Berdasarkan wawancara dengan Mutiarisman (tanggal 27 Maret 2018 di Nagari Tanjung Sani) mengungkapkan ada 2 jenis tubo. Pertama, tubo siareh yaitu tubo yang terjadi waktunya lama dan berpindah-pindah, ditandai air danau berwarna hitam. Hal ini terjadi apabila selama 3 hari berturut-turut hujan tanpa henti atau musim kabut tidak ada cahaya matahari. Kedua, tubo belerang, yaitu tubo yang terjadi karena ada angin darat dan air danau berbau belerang.

Bagi petani keramba, jika terjadi tubo, mereka menyebutnya sebagai bunian baralek, yaitu makhluk yang tak nampak di mata manusia, sebangsa kaum jin yang sedang mengadakan pesta. Berdasarkan wawancara dengan Andi Irmanto (27 Maret 2018 di Nagari Tanjung Sani) bahwa pada saat tubo terjadi, maka ikan muncul ke permukaan. Kondisi ikan itu pusing-pusing dan umumnya petani keramba akan segera mengambil dengan menggunakan serokan atau tangguak. Tidak hanya ikan, rinuak juga banyak muncul. Menurut masyarakat setempat, rinuak adalah sejenis ikan yang kecil-kecil dan hidup hanya di danau Maninjau. Ukuran rinuak kurang dari $1 \mathrm{~cm}$ dengan lebar badan rata-rata $1 \mathrm{~mm}$. Rinuak memiliki tubuh yang transparan dan hidup bergerombolan di Danau Maninjau. Rinuak hidupnya berkelompok terutama di tempattempat yang terlindung dari cahaya matahari seperti permukaan danau yang tertutup daun-daunan. Sebelum ada KJA, masa tubo itu terjadi selama 2 (dua) bulan yang diistilahkan dengan manundo kapa naik haji.

Menurut sebagian petani KJA, pada masa tubo setelah ikan mati, 
perkembangan ikan akan bagus. Logikanya ikan mati dibiarkan di danau membusuk, hancur oleh bakteri, jamur, dan virus. Tubuh ikan itu terdiri dari protein, karbohidrat, lemak, dan ketika pembusukan itu dihasilkan senyawasenyawa lain dari badan ikan. Zat-zat yang terurai jadi pupuk sehingga pertumbuhan fitoplankton dan zooplankton makin banyak sebagai sumber makanan ikan. Kondisi ini dimanfaatkan untuk menebar bibit ikan (Wawancara dengan $\mathrm{M}$. Badjoeri, 27 Maret 2018).

Pemanfaatan Danau Maninjau sebagai KJA telah berdampak pada keseimbangan ekosistem. Berdasarkan wawancara dengan M. Badjoeri (tanggal 28 Maret 2018) bahwa pemanfaatan danau sebagai KJA telah mengubah ekosistem danau dan menghasilkan proses kimia seperti $\mathrm{H}_{2} \mathrm{~S}$ (sulfur) belerang (sulfida) berasal dari proses perombakan bahanbahan organik dari dasar danau dan senyawa $\mathrm{H}_{2} \mathrm{~S}$. Proses merombak senyawa sulfi ${ }^{1}$ itu membutuhkan oksigen, sehingga ikan mati di danau akibat kekurangan oksigen.

Peristiwa upwealing (tubo) secara ilmu pengethuan dapat dijelaskan sebagai berikut (1) Adanya lapisan air di danau akibat ada perbedaan suhu di air. Suhu dipermukaan, kedalaman satu meter, lebih dari 1 meter sampai ke dasar akan terjadi perbedaan suhu yang berpengaruh terhadap aktivitas yang ada di dalam danau. Lapisan yang mengandung oksigen di danau yang ada sekarang ini sudah semakin tipis. Jika ada retakan di bawah atau angin di atas maka pada bagian bawah yang oksigennya sedikit akan naik ke atas. (2) Adanya perbedaan suhu permukaan dengan yang di bawah. Biasanya suhu yang di bawah itu lebih dingin dibandingkan yang di atas. Pada saat panas seperti ini yang menyimpan suhu yang stabil adalah yang di bawah. Misalnya permukaan di atas

1 Perombakan sulfida dari gunung merapi maupun sisa pakan ikan yang mengendap di danau. bersuhu $27^{\circ} \mathrm{c}$ dan di bawah $26^{\circ} \mathrm{c}$. Suhu di bawah akan lebih stabil walaupun berubah hanya koma dan tidak pernah merlonjak. Sementara suhu yang atas terkena panas akan melonjak. Namun demikian, jika hujan terjadi terus menerus, suhu yang di atas akan turun bahkan bisa lebih rendah dari yang di bawah. Ketika suhu di permukaan lebih rendah dari yang di bawah maka berat jenis air yang hangat lebih ringan (ada di bawah), akan berputar dan naik ke air yang di bawah tadi, dan terjadilah upwealing. Saat arus berputar, air di bawah banyak mengandung sedimen, racun-racun yang terbawa ke atas (Wawancara dengan M. Badjoeri, 27 Maret 2018). Penjelasan terkait konsep tubo bisa dibaca lebih lanjut di Badjoeri (2016).

Berbagai istilah yang berkembang di tengah petani keramba, yaitu tubo, upwealing, dan umbalan. Pengertian tubo belerang menurut Lukman, Sutrisno, dan Hamdani (2013) yakni istilah yang ditandai dengan adanya kematian massal ikan yang dipelihara pada KJA. Umbalan terjadi akibat penumpukan bahan organik yang kemudian ditumbuhi oleh organismeorganisme yang ketika mati, di mana organisme itu naik ke permukaan air. Istilah umbalan jarang digunakan dan lebih banyak disebut upwealing atau pembalikan massa air.

Peristiwa tubo dapat dilihat dari sudut ekologis, yaitu hubungan antara kegiatan manusia dan proses alam. Perubahan ekologis kaitannya dengan kebudayaan juga dapat sekaligus membuat manusia menyesuaikan berbagai gagasan mereka. Perubahan ekologis bisa terjadi disebabkan oleh alam atau oleh berbagai aktivitas manusia terhadap alam tersebut untuk pemenuhan kebutuhan ekonomi manusia. Jika eksploitasi lingkungan tidak memikirkan daya dukung yang dimiliki, lingkungan pun akhirnya terkorbankan. Sehingga manusia melalui kebudayaannya harus mampu beradaptasi dengan cara selalu melakukan penyesuaian diri terhadap lingkungan biogeofisik maupun 
lingkungan sosial budaya para pendukungnya (Purwanto, 2000).

Para petani KJA secara tradisional memiliki pengetahuan tentang tanda-tanda akan terjadinya tubo, seperti keadaan mendung selama dua hari di sekitar Danau Maninjau yang menurut mereka berbeda jika mendung sebagai tanda akan turun hujan seperti ummnya. Namun tanda-tanda alam tersebut tidak serta merta akan menimbulkan tubo sehingga para Petani KJA dapat melakukan upaya untuk mengurangi kerugian seperti panen lebih awal.

Sebagian besar petani KJA menganggap bahwa tubo adalah siklus alam. Peristiwa tubo yang terjadi pada saat ini sama dengan peristiwa tubo yang terjadi pada zaman dahulu. Alamlah yang dianggap sebagai penyebab dari tubo, sehingga tidak ada hal yang bisa dilakukan oleh manusia. Padahal peristiwa tubo yang terjadi saat ini berbeda dengan yang terjadi pada masa lampau. Pada zaman dahulu, peristiwa tubo murni terjadi karena aktivitas belerang, tetapi pada saat sekarang ini, peristiwa tubo terjadi sudah bercampur dengan penyebab dari sisa-sisa pakan ikan terendam, tetapi masyarakat, khususnya petani KJA, tetap menganggap tidak ada hubungannya.

Sebagai peristiwa alamiah, Petani KJA mengatakan bahwa dengan peristiwa tubo mereka tetap diuntungkan. Menurut Petani KJA, dengan adanya tubo membawa keuntungan. Ikan yang mati akan mengambang dan menjadi plankton yang nantinya akan berguna bagi kesehatan ikan-ikan yang hidup. Petani KJA mengatakan ikan yang mati tidak membawa kerugian ekonomis bagi mereka. Hal ini karena ketika memasukkan bibit, petani KJA sudah memperhitungkan setengah bibitnya pasti akan mati. Jadi ketika ikan yang dimasukkan hanya tinggal setengah, bagi mereka itu tetap sebuah keuntungan. Demikian pandangan bagi sebagian petani KJA, peristiwa tubo adalah siklus alam yang tidak bisa diubah melainkan harus diterima. Persepsi ini berlawanan dengan persepsi pemerintah yang menganggap peristiwa tubo dan kematian ikan adalah suatu kegagalan.

Selain itu, ada juga petani KJA yang memiliki wawasan lingkungan dan menganggap bahwa peristiwa tubo terjadi karena sisa pakan terendam yang menumpuk di dasar danau. Pakan yang diberikan terhadap ikan merupakan bagian dari akivitas ekonomi masyarakat yaitu keramba. Ada sebagian masyarakat yang percaya bahwa aktivitas ekonomi mereka yaitu berkeramba bisa merusak keseimbangan ekosistem Danau Maninjau. Sehingga mereka akhirnya beralih dengan memberikan pakan terapung. Tetapi jumlah petani KJA yang mengerti dan memiliki wawasan lingkungan hanya sedikit, sehingga tetap kalah jumlah dari petani KJA yang menggunakan pakan terendam.

Petani KJA menganggap bahwa aktivitas ekonomi mereka sepenuhnya didukung oleh alam, yaitu keberadaan Danau Maninjau. Mereka merasa bahwa menjadi petani KJA adalah tuntunan dari alam yang ada di sekitar mereka, alam menyediakan sumber daya, dan alam akan mampu menampung "hasil" dari semua aktivitas ekonomi mereka termasuk sisa pakan dianggap sebagai bagian dari ekosistem.

Sesuai dengan pendapat Steward (1955) bahwa masyarakat di Danau Maninjau memiliki pengetahuan yang menganggap alam memiliki sistem tersendiri dalam menanggapi kehidupan manusia. Mereka menganggap bahwa alam memang bukanlah sesuatu hal yang bisa mereka taklukkan, sehingga pengetahuan mereka menuntun mereka untuk menerima semua hal dari alam. Termasuk tubo yang ada di Danau Maninjau. Sesuai dengan pengetahuan masyarakat, tubo di Danau Maninjau dianggap sebagai sesuatu hal yang berada di luar jangkauan manusia. Oleh sebab itu, petani KJA menganggap bahwa tubo adalah hal yang pasti terjadi, sehingga tidak ada yang bisa mereka lakukan selain 
menerima, dan menganggap itu sebagai sebuah bencana.

Hal lainnya yang bisa dijadikan sebagai alat analisis dari teori Steward (1955) mengenai ekologi budaya yaitu hubungan timbal balik antara manusia, lingkungan, dan eksploitasi. Dalam kaitannya dengan petani KJA terdapat hubungan timbal-balik antara petani KJA dan ekosistem danau. Petani KJA menyediakan bibit ikan yang sangat berguna bagi ekosistem danau, dan petani KJA juga mendapatkan manfaat ekonomis dari ekosistem danau. Namun demikian, dalam hubungan timbal balik tersebut terjadi proses eksploitasi oleh petani KJA terhadap ekosistem danau. Dalam hubungan timbal balik antara Danau Maninjau dan petani KJA, ekositem danaulah yang mendapatkan eksploitasi dari petani KJA, sehingga hal inilah yang dilihat oleh Steward sebagai hubungan timbal balik yang menghasilkan eksploitasi. Konsep yang digunakan oleh Julian Steward dalam memahami ekologi budaya yaitu setelah terjadinya eksploitasi, maka pola perilaku ekologi masyarakat akan mengarah ke tingkat yang mana pola perilaku cenderung ke sektor lain dari budaya. Ketika terjadi ekspoitasi akibat dari tindakan ekonomi masyarakat yang merupakan hasil dari hubungan timbal balik antara manusia dan lingkungan, masyarakat akan mengarahkan tindakannya terhadap lingkungan, selain dari tindakan budaya. Petani KJA akan mengalihkan bencana yang ada di Danau Maninjau dengan cara menganggap tubo yang terjadi di Danau Maninjau tidak bisa diprediksi dan tidak bisa diatasi oleh manusia. Petani KJA menganggap bahwa tubo di Danau Maninjau adalah sesuatu di luar kuasa manusia sehingga mereka akan menganggapnya sebagai "pemberian dari alam". Hal inilah yang menyebabkan sebagian besar petani KJA menganggap bahwa kegagalan mereka dari peristiwa tubo merupakan hal yang lumrah. Mereka tidak merasa rugi ataupun gagal ketika peristiwa tubo terjadi karena mereka sudah memprediksi dan menganggap hal itu tidak bisa dihindari.

\section{Strategi Adaptasi}

Purwanto (2000) mengungkapkan bahwa hubungan antara manusia dengan lingkungannya biogeofisik tidak hanya merupakan hubungan ketergantungan semata, melainkan juga terwujud dalam bentuk hubungan saling memengaruhi dan mampu mengubah lingkungan geofisik tersebut. Dengan mengutip pendapat Alland dan Haris, Marfai (2013) mendefenisikan adaptasi sebagai suatu strategi penyesuaian diri yang digunakan manusia selama hidupnya untuk merespon terhadap perubahan-perubahan lingkungan dan sosial. Menurut Sahlin dan Morran seperti yang dikutip oleh Marfai (2013) juga mengungkapkan bahwa proses adaptasi sangatlah dinamis karena lingkungan dan populasi manusia berubah terus. Sehingga ketika masyarakat mulai menyesuaikan diri terhadap lingkungan yang baru, suatu proses perubahan akan dimulai dan (mungkin) membutuhkan waktu yang lama untuk dapat menyesuaikan diri. Strategi adaptasi menurut Soekanto (2006) merupakan proses mengatasi halangan dan proses perubahan untuk menyesuaikan diri dengan lingkungan yang baru. Soekanto (2006) membagi adaptasi menjadi tiga macam yaitu: (1) adaptasi terhadap lingkungan eksternal fisik, (2) adaptasi terhadap sosial budaya, dan (3) adaptasi terhadap kondisi kehidupan efektif.

Tidak hanya adaptasi terhadap lingkungan secara fisik, tetapi juga terkait dengan sosial budaya. Menurut Ahimsa seperti yang dikutip oleh Irmanto (1998) menyatakan bahwa strategi sosial merupakan bentuk usaha yang dirancang manusia untuk memenuhi syarat minimal yang dibutuhkannya dan untuk mencegah masalah-masalah yang dihadapi. Jadi strategi adalah pilihan tindakan yang dilakukan untuk memecahkan suatu permasalahan. Strategi dipilih sesuai dengan permasalahan yang dihadapi, dan 
jika strategi yang dipilih tidak memberikan hasil yang baik, maka strategi lain dilakukan dalam usaha mendapatkan capaian yang diinginkan (Abdoellah, 2017).

Jadi dapat disimpulkan bahwa strategi adaptasi adalah pilihan tindakan yang dilakukan secara terus menerus dalam usaha mengatasi perubahan yang terus berlangsung. Hal ini karena manusia akan terus berjuang untuk dapat bertahan demi kelangsungan hidupnya. Adapun hasil dari proses adaptasi tersebut ada yang berhasil sesuai keingian, namun ada juga yang tak berhasil. Semua terjadi berkat usaha yang dilakukan manusia terhadap keberlangsungan hidupnya.

Masyarakat di Kawasan Danau Maninjau pada dasarnya telah menyadari berbagai dampak, yaitu ikan asli Danau Maninjau seperti rinuak (Psilopsis sp), pensi (sejenis kerang kecl), dan langkitang (sejenis siput). Disamping itu juga memberi dampak terhadap pariwisata dengan menurunnya kunjungan wisatawan nusantara dan mancanegara (Nanda et al., 2018). Namun kemudahan dan keuntungan yang diperoleh sebagai Petani KJA membuat mereka memperioritaskan KJA.

Manusia tidak hanya harus mampu beradaptasi pada lingkungan alam semata, namun juga harus mampu berdaptasi pada lingkungan sosial dan budayanya sehingga dapat hidup pada kondisi dinamis. Memanfaatkan peluang besar yang diambil pada saat jumlah pariwisata ke Maninjau menurun untuk keberlangsungan hidup. Berbagai kemudahan yang didapat untuk menjadi petani KJA pada saat itu antara lain peminjaman modal, baik untuk pengadaan keramba, bibit, maupun pakan, serta kemudahan mengurus perizinan. Oleh karena itulah kesempatan tersebut banyak dimanfaatkan baik oleh para masyarakat sekitar maupun para pemodal dari luar Maninjau. Seharusnya berbagai peluang dan kemudahan itu tidak hanya diambil semata tetapi juga harus mempertimbangkan kemampuan alam yang dimiliki Danau Maninjau. Menurut
Endah and Nadjib (2017) ada kepentingan investor dari luar (tokei) sehingga petani KJA berusaha untuk selalu meningkatkan produksi ikan dengan cenderung mengabaikan pelestarian danau.

Tubo yang terjadi secara alami akan terus terjadi selama retakan bekas letusan mengeluarkan belerang. Demikian juga tubo akibat dari penumpukan sisa pakan akan terus menjadi bencana bagi petani KJA. Pengalihan pekerjaan para petani KJA dengan tidak lagi menjadikan sumber mata pencaharian utama tentu membutuhkan proses dan waktu yang tak sebentar, dan diprediksi dapat dicapai selama 10 tahun. Keadaan ini memaksa petani KJA melakukan berbagai cara untuk dapat bertahan di lingkungan yang mengalami perubahan tersebut.

Pada dasarnya masyarakat Kawasan Danau Maninjau bukanlah masyarakat maritim tetapi masyarakat agraris yang memfokuskan mata pencahariannya di darat sebagai petani (Endah \& Nadjib, 2017). Aturan maupun kearifan lokal dalam pengelolaan darat sudah ada dan didukung oleh lembaga adat. Namun dalam hal pengelolaan danau tidak diatur sehingga danau dianggap tidak bertuan dan dapat dimanfaatkan siapa saja (Nanda et al., 2018).

Pada tahun 2017 Petani KJA mulai menyadari bahwa dengan memperbanyak keramba tidak otomatis akan memperbanyak jumlah ikan, sehingga mereka lebih memfokuskan pada kualitas ikan yang hidup, dengan cara mengurangi jumlah keramba hingga berjumlah 17.226.

Sebagian besar petani KJA tetap bertahan dengan KJA dan menerapkan pola lama walaupun mereka harus mengalami peristiwa tubo. Strategi dalam mengurangi kerugian akibat tubo dilakukan dengan lebih banyak mempelajari pengalaman sebelumnya secara mandiri oleh kelompok petani KJA. Strategi yang dilakukan oleh para petani KJA yang masih bertahan adalah sebagai berikut: 
1. Mempelajari kondisi cuaca. Informasi diperoleh dari BMKG (Badan Meteorologi dan Geofisika), dari para peneliti LIPI (Lembaga Ilmu Pengetahuan Indonesia), maupun informasi yang disebarkan oleh pemerintah nagari. Dengan mengetahui informasi cuaca maka akan lebih cepat tanggap mengantisipasi tubo;

2. Mengurangi kapasitas ikan di setiap unit KJA agar jumlah oksigen lebih banyak tersedia;

3. Memilih bibit yang sehat salah-satu ilmu yang harus dimiliki oleh petani keramba. Hal yang harus diperhatikan adalah ukuran bibit yang sesuai dengan jaring. Bibit ikan yang dipilih memiliki ukuran yang relatif sama dan tidak dicampur dalam satu jaring dengan ukuran yang berbeda;

4. Menambah luas ukuran keramba dan jumlah ikan yang dikurangi ${ }^{2}$;

5. Tidak memberi makan pakan dengan pellet karena danau menyediakan makanan berupa plankton-plankton;

6. Ikan yang layak panen harus segera dipanen untuk memisahkan ikan sesuai ukuran atau memindahkan ikan lainnya ke air yang lebih jernih;

7. Mengetahui kapan cuaca baik dan tidak baik untuk memulai memasukkan bibit ke dalam keramba. Biasanya mulai dari bulan September sampai bulan Januari cuaca tidak stabil sehingga bukan waktu yang tepat untuk memasukkan bibit. Justru terus mengawasi keadaan ikan yang sudah ada dalam keramba agar bisa ditangani secepat mungkin jika cuaca mulai tidak baik. Bulan Maret diyakini sebagai waktu yang baik untuk memasukkan bibit ke KJA;

\footnotetext{
${ }^{2}$ Seperti yang dilakukan oleh salah satu petani keramba bernama Yanrizal, yakni ukuran keramba $6 \mathrm{~m} \times 12 \mathrm{~m}$ maksimal diisi sekitar 10.000 ekor, sebelumnya diisi hingga sekitar 50.000 ekor. Dengan diisi 10.000 ekor dengan luas $6 \mathrm{~m} \times 12 \mathrm{~m}$ maka ikan bebas bernafas meski air terkena tubo
}

8. Harga ikan di pasar tidak bisa dipastikan sehingga keuntungan hasil panen juga tidak bisa diprediksi. Dengan memahami tubo, kemungkinan mendapat keuntungan akan semakin besar karena kemungkinan ikan dari KJA lainnya banyak yang mati sehingga produksi sangat sedikit;

9. Tetap fokus berkeramba meski harus memulai kembali dari nol dan memilih ikan Nila dibandingkan ikan Majalaya karena situasi danau yang tidak stabil, dan ikan Nila lebih kuat dibandingkan dengan ikan Majalaya.

Pengalaman peristiwa tubo pada sebagian petani KJA tidak memberi dampak secara signifikan untuk mengalihkan usaha ke sektor lain. Justru mencari alternatif lain dalam cara pengelolaan KJA. Peristiwa tubo dijadikan sebagai motivasi untuk mencari solusi agar KJA miliknya bisa berhasil pada musim panen berikutnya. Solidaritas sesama petani KJA semakin kuat untuk saling membantu secara modal maupun mental. Dengan solidaritas ini maka petani KJA memiliki percaya diri dan motivasi untuk melanjutkan usaha KJA (wawancara dengan Yanrizal tanggal 26 Maret 2018 di Tanjung Sani).

\section{Kerjasama Antara Pemerintah dan Petani KJA}

Pada tahun 2016 Pemerintah Provinsi Sumatera Barat telah menetapkan kebijakan dalam rangka penyelamatan Danau Maninjau, yaitu: pengelolaan ekosistem danau, pemanfaatan sumber daya air danau, mengembangkan sistem monitoring evaluasi dan informasi, langkah-langkah baik dari informasi yang diperoleh, pengembangan kapasitas kelembagaan dan koordinasi, peningkatan peran masyarakat dalam bentuk pencegahan (preventif) atau penyelesaian masalah (solutif), dan pendanaan yang berkelanjutan (Bappeda Sumatera Barat, 2019).

Dalam rangka mengembalikan daya tampung Danau Maninjau terhadap KJA 
sesuai Perda Nomor 5 tahun 2014 tentang Pengolahan Kelestarian Danau Maninjau hanya 6.000 petak KJA, dilakukan beberapa upaya bersama pemerintah setempat maupun pemerintah pusat terkait penyelamatan para petani KJA antara lain (Pemerintah Kabupaten Agam, 2014):

1. Pendataan mengenai jumlah keramba yang telah dilakukan mengenai pemilik KJA di Maninjau. Pendataan yang belum merata di seluruh wilayah Danau Maninjau. Terkait pengurangan jumlah keramba menjadi 6000 petak sementara jumlah petak yang ada jauh melebihi daya tampung danau, maka harus ada kebijakan yang jelas terkait siapa saja yang berhak untuk memiliki KJA.

2. Mengenalkan cara mengelola keramba dengan pemakaian vitamin dan mengurangi pemakaian pellet.

3. Pengendalian harga ikan. Hal ini sangat dirasakan oleh petani KJA dengan harga ikan yang tidak stabil. Harga ikan yang jauh menurun menyulitkan para petani untuk menjual ikan padahal waktu panen sudah tiba. Oleh karena itu para toke mengurangi jadwal memanen di masyarakat karena banyak pilihan daerah lain untuk panen dengan harga produksi murah. Panen ikan banjir di beberapa daerah seperti di Bangkinang, Teluk Kuantan, Rao Pasaman, sehingga bagi para toke lebih menguntungkan mengambil ikan di daerah-daerah selain Maninjau. Bagi petani harga murah yang mereka rasakan sejak Hari Raya Idul Adha yang semula harga ikan masih Rp. $23.000 / \mathrm{kg}$ saat ini turun menjadi Rp.18.000/kg, padahal harga pakan terus naik. Saat ini jika ikan belum juga dipanen padahal sudah waktunya untuk panen, maka ongkos produksi untuk ikan terus bertambah karena ikan akan tetap diberi makan meski hanya sekali sehari. Belum lagi petani merasa khawatir, takut tubo datang suatu waktu. ${ }^{3}$

4. Mengenalkan pengolahan ikan hasil panen. Selama ini ikan yang dipanen sebatas ikan segar, sedangkan ikan salai (pengawetan dengan pengasapan) tidak terlalu berkembang. Pengolahan tersebut bisa diajarkan pada kaum perempuan dan remaja sehingga bisa menambah penghasilan keluarga. Memudahkan pula sistem pengemasan dan pemasaran sehingga potensi Danau Maninjau menjadi nilai jual yang tinggi yang mendatangkan keuntungan bagi masyarakat setempat.

5. Pemberian bibit tanaman yang sesuai dengan kondisi lahan pertanian oleh pemerintah sebagai alternatif mata pencaharian petani KJA selain bidang perikanan. Pemerintah Kabupaten Agam sudah memberikan bibit, namun pembagian bibit tersebut tidak merata hanya segelintir orang saja yang mendapatkan bibit tersebut. Kemudian setelah bibit diberikan hendaknya ada sosialisasi bagaimana pemeliharaan bibit hingga hasilnya bisa maksimal. Masyarakat mengeluhkan bahwa bibit yang diberi sebagian menghasilkan dengan baik, seperti alpukat namun begitu yang menjadi kendala bagi masyarakat adalah kemudahan dalam pemasaran dan harga yang menguntungkan bagi masyarakat.

6. Menjadikan Danau Maninjau kembali menjadi daerah wisata yang lebih edukatif. Salah satunya menjadikan usaha berkeramba tidak hanya bisa dinikmati oleh petani keramba, tetapi juga oleh para pengunjung Maninjau. Mereka datang ke Maninjau menikmati alam dan menikmati kuliner di sana.

7. Memberikan ketrampilan mengolah eceng gondok yang sudah melimpah di Danau Maninjau. Pemerintah telah memberikan alatnya berupa mesin

\footnotetext{
${ }^{3}$ Wawancara via telpon dengan Andi Irmanto (petani KJA di Maninjau) 1 November 2018 terkait dengan harga panen ikan saat ini.
} 
pencacah. Masyarakat dipandu untuk mengolah limbah ini agar bisa menjadi hasil olahan yang berdaya guna dan berdaya jual tinggi berupa Pupuk Padat (Gembur), Pupuk Padat (Kascing), Pupuk Cair, Biogas, Pakan Ikan (Pelet), Pakan Itik, Pakan Domba dan Sapi, Pengurai Septic, Tank, Agensi Hayati, Briket. Setelah itu diberi pula pelatihan untuk memasarkan hasil olahan eceng gondok sehingga menjadi penghasilan tambahan bagi masyarakat.

8. Upaya penyelamatan Danau Maninjau tidak bisa berjalan dengan baik jika tidak didasari rasa memiliki bersama. Pemerintah tidak bisa melakukan sesuai dengan kehendaknya saja, begitu pula masyarakat harus memiliki rasa peduli. Butuh kerjasama yang baik sehingga antara pemerintah dan masyarakat bisa saling mengerti tindakan apa yang harus dilakukan sehingga semua terselamatkan.

\section{PENUTUP}

Kejadian tubo yang berulang-ulang pada akhirnya membuat kerugian besar tidak hanya pada petani KJA secara ekonomi, tetapi juga kerusakan ekosistem. Dengan kemampuan daya tampung Danau Maninjau terhadap KJA hanya sebatas 6000 dibandingkan dengan jumlah KJA saat ini, tidak hanya merugikan masyarakat sekitar dalam pemanfaatan danau dalam akvitas kehidupan sehari-hari, tetapi juga merusak sektor perekonomian lainnya.

Keuntungan yang diperoleh mengakibatkan petani KJA melupakan persoalan daya tampung danau dan tubo. Petani KJA menyikapi peristiwa tubo sebagai peristiwa alami yang harus diterima. Berdasarkan analisis ekologi budaya, petani KJA tetap bertani KJA namun beradaptasi dengan kondisi lingkungan alam seperti mempelajari penyebab dan musim terjadinya tubo, mengubah KJA dengan ukuran yang lebih besar, dan pembatasan pemberian pakan ikan pada saat-saat tertentu.
Nilai budaya yang memandang Danau Maninjau sebagai sebagai milik bersama yang bisa dimanfaatkan seluasluasnya mulai diubah dengan pemahaman bahwa alam juga punya keterbatasan sehingga ada kesepakatan yang ditetapkan secara adat dan ditindaklanjuti dengan peraturan daerah. Hal ini dilakukan sebagai adaptasi budaya terhap lingkungan alam mereka. Dengan demikian pemanfaatan Danau Maninjau sebagai sebagai lahan KJA tetap dilakukan.

Belajar dari apa yang telah terjadi, maka diperlukan kearifan para petani dalam memanfaatkan sumber daya alam yang terdapat di danau. Keramba Jaring Apung tidak boleh melebihi daya dukung danau. Untuk itu harus ada upaya yang jelas yang harus dilakukan oleh Petani KJA, ninik mamak, dan pemerintah untuk menjalankan kesepakatan yang telah dibuat sebagai upaya meningkatkan sumber daya ekonomi masyarakat sekitar. Bagi petani KJA, adaptasi yang mereka lakukan adalah sekedar upaya bertahan hidup di tengah kondisi alam yang memiliki keterbatasan.

\section{DAFTAR SUMBER}

Abdoellah, O. S. (2017). Ekologi Manusia dan Pembangunan Berkelanjutan. Gramedia.

Afrizal. (2014). Metode Penelitian Kualitatif: Sebuah Upaya Mendukung Penggunaan Penelitian Kualitatif Dalam Berbagai Disiplin Ilmu. RajaGrafindo Persada.

Andi Irmanto (27 Maret 2018) Wawancara.

Ardi, I. (2013). Budidaya Ikan Sistem Keramba Jaring Apung Guna Menjaga Keberlanjutan Lingkungan Perairan Waduk Cirata. Media Akuakultur, 8(1), 23-29.

Badjoeri. (2016). Kondisi Pencemaran dan Kerusakan Danau Maninjau terhadap Biota Danau. LIPI.

Bappeda Sumatera Barat. (2019). Pengelolaan Danau Maninjau dan Danau Singkarak Harus secara Komprehensif dan Berkelanjutan. https://bappeda.sumbarprov.go.id/home/n ews/85-pengelolaan-danau-maninjau- 
dan-danau-singkarak-harus-secarakomprehensif-dan-berkelanjutan.html

Endah, N. H., \& Nadjib, M. (2017). Pemanfaatan dan Peran Komunitas Lokal dalam Pelestarian Danau Maninjau. Jurnal Ekonomi dan Pembangunan, 25(1), 55-67.

Fransiska, M. (2019). Adaptasi Ekologi Penduduk Transmigrasi di Desa Rasau Jaya Satu. Pangadereng, 6(1), 1-12.

Helmi, Alfian, \& Arif, S. (2012). Strategi Adaptasi Nelayan Terhadap Perubahan Ekologis. Jurnal Makara Sosial Humaniora, 6(1), 68-78.

Imam (27 Maret 2018) Wawancara.

Irmanto, A. (1998). Strategi Masyarakat Desa dalam menghadapi Dampak Negatif Kegiatan Pariwisata di Lokasi Wisata Danau Maninjau Studi Kasus di Desa Pasar Maninjau Kecamatan Tanjung Raya Kabupaten Agam. Universitas Andalas.

Kristiawan, N. (2017). Pola Adaptasi Ekologi Budaya Tiga Komunitas di Jambi. Bhumi, 3(2), 189-200.

Lukman, Sutrisno, \& Hamdani, A. (2013). Pengamatan Pola Stratifikasi di Danau Maninjau Sebagai Potensi Tubo Belerang. LIMNOTEK - Perairan Darat Tropis Di Indonesia, 20(2), 129-140.

M. Badjoeri ( 27 Maret 2018) Wawancara.

M. Badjoeri (28 Maret 2018) Wawancara.

Marfai, M. A. (2013). Pengantar Etika Lingkungan dan Keraifan Lokal. Gadjah Mada University Press.

Marzuki, F., \& Ali, S. (2018). Memberdayakan Ekonomi Ukm Menyelamatkan Danau Maninjau Dari Pencemaran Dan Kerusakan Lingkungan. Jurnal Ipteks Terapan, $\quad 12(1), \quad 84$ https://doi.org/10.22216/jit.2018.v12i1.2 912

Mutiarisman (27 Maret 2018) Wawancara.

Mutiarisman (28 Maret 2018) Wawancara.

Nanda, L. D., Tan, F., \& Noer, M. (2018). Tingkat Partisipasi Masyarakat Dalam Program Berkelanjutan Danau Maninjau. Jurnal Kebijakan Sosial Ekonomi
.Kelautan Perikanan, 8(2), 105-115. https://doi.org/10.15578/jksekp.v8i2.743 2

Noferi, I. (2003). Dampak Sosial Ekonomi dari Pencemaran Danau Maninjau Studi Kasus: Kecamatan Tanjung Raya Kabupaten Agam. http://lib.ui.ac.id//opac/ui/detail.jsp?=717 80\&lokasi=lokal

Pemerintah Kabupaten Agam. (2014). Peraturan Daerah Kabupaten Agam Nomor 5 Tahun 2014.

Praditya, D., Sabar, \& Yulia, R. (2014). Kehidupan Sosial Ekonomi Petani Ikan Keramba di Desa Tanjung Sani Maninjau Kecamatan Tanjung Raya Kabupaten Agam. Jurnal Sejarah, 3(2).

Pribadi, A., Mulyadi, E., \& Pratomo, I. (2007). Mekanisme Erupsi Ignimbrit Kaldera Maninjau, Sumatera Barat. Jurnal Geologi Indonesia, 2(1), 31-34.

Puhili, I. S. (2013). Adaptasi Budaya Suku Komoro Lingkungan Industri PT. Freeport di Distrik Mimika Timur. Jurnal Hiyakhe, 3(1), 159-169.

Purwanto, H. (2000). Kebudayaan dan Lingkungan dalam Perspektif Antropologi. Pustaka Pelajar.

Soekanto, S. (2006). Sosiologi Suatu Pengantar. Raja Grafindo Persada.

Steward, J. H. (1955). Theory of Culture Change: The Methodology of Multilinear Evolution. Univ of Illinois Pr.

Sutton, M. Q., \& Anderson, E. N. (2014). Introduction To Cultural Ecology. AltaMira Press.

Syandri. (2016). Dampak Budidaya Ikan dengan Keramba Jaring Apung terhadap Kondisi Danau Maninjau, makalah dipresentasikan tanggal 1 Desember 2016.

Syandri, H., Junaidi, Elfiondri, \& Azrita. (2015). Social Status of the Fish-farmers of Floating-net-cages in Lake Maninjau, Indonesia. Journal of Aquaculture Research \& Development, 07(01), 1-5. https://doi.org/10.4172/21559546.1000391

Yanrizal. (26 Maret 208). Wawancara 
